\title{
B7-H4 is highly expressed in aggressive Epstein-Barr virus positive diffuse large B-cell lymphoma and inhibits apoptosis through upregulating Erk1/2 and Akt signalling pathways
}

\author{
Ying Jiang ${ }^{1}$, Gangli Cai ${ }^{2}$, Jun Lin ${ }^{3}$, Jing Zhang ${ }^{4}$, Zhilei Bo ${ }^{1}$, Ying Li ${ }^{1}$, Chun Wang ${ }^{1 *}$ and Yin Tong ${ }^{1 *}$ (D
}

\begin{abstract}
Background: B7-H4 is among the B7 family members which may serve as a new targetable immune checkpoint molecule. It was reported that high level of serum B7-H4 level may be correlated with lymphoma. Nevertheless, the role of B7-H4 in Epstein-Barr Virus-Positive diffuse large B cell lymphoma (EBV ${ }^{+} D L B C L$ ) has not been addressed although it has been suggested that B7-H4 could promote tumor growth and metastatic progression in certain cancers.

Methods: Between January 2005 and November 2017 at the department of Hematology, Shanghai Jiao Tong University School of Medicine affiliated Shanghai General Hospital 260 DLBCL samples were analyzed for EBV-encoded small RNA (EBV-EBER) by in situ hybridization. The expression level of B7-H4 in DLBCL tumor tissue was evaluated by immunohistochemistry. Furthermore, the role of B7-H4 in DLBCL was further investigated in DLBCL cell line.

Results: $E B V^{+} D L B C L$ patients suffered from markedly lower overall survival (OS) and progression-free survival (PFS) rates in our study. We showed that B7-H4 was significantly overexpressed in $16 \mathrm{EBV}^{+}$-subgroup cases out of $260 \mathrm{DLBCL}$ patients. We further found that EBV infection in lymphoblast cells led to enhanced expression of B7-H4 followed by increased cell viability and reduced apoptosis. In contrast, inhibition of B7-H4 simultaneously impaired cell viability and induced apoptosis. Mechanistically, inhibiting B7-H4 resulted in decreased phosphorylation Erk 1/2 and Akt.
\end{abstract}

Conclusion: Our study reveals a critical role of $\mathrm{B} 7-\mathrm{H} 4$ in $\mathrm{EBV}^{+} \mathrm{DLBCL}$ development by regulating cell survival and apoptosis through the Erk and Akt signalling pathways. Targetting B7-H4 may be promising in the therapy of $E B V^{+} D L B C L$.

Keywords: Epstein-Barr virus positive diffuse large B cell lymphoma, B7-H4, Apoptosis

\section{Background}

Epstein-Barr Virus (EBV) positive diffuse large B Cell lymphoma $\left(\mathrm{EBV}^{+} \mathrm{DLBCL}\right)$ is an aggressive disease with poor prognosis when treated with conventional chemotherapy [1]. New therapeutic approaches are needed for this type of lymphoma. Some research attributed the mechanisms of $\mathrm{EBV}^{+} \mathrm{DLBCL}$ to immunosenescence.

\footnotetext{
*Correspondence: wangchunsgh@126.com; tongyin_cn2@hotmail.com Ying Jiang, Gangli Cai and Jun Lin are the co-first authors.

'Department of Hematology, Shanghai General Hospital, Shanghai Jiao Tong University School of Medicine, 100 Haining Road, Shanghai 200080, People's Republic of China

Full list of author information is available at the end of the article
}

Also, some signalling pathways were considered to be involved in the mechanisms of $\mathrm{EBV}^{+} \mathrm{DLBCL}$, such as CD30, NF-kB and PD-1 $[1,2]$. In recent years, immune checkpoint blockage strategies have emerged as a promising targeting therapy. PD- 1 antibody shows therapeutic value in DLBCL [3]. However, still a part of patients remains resistant to these blockages. We tried to explore the other possible immune checkpoint associated with the pathogenesis of $\mathrm{EBV}^{+} \mathrm{DLBCL}$.

Besides PD-1, there is another immune negative checkpoint: B7-H4. B7-H4 is among the B7 superfamily, which is shown to have inhibitory effects on T-cell

(C) The Author(s). 2019 Open Access This article is distributed under the terms of the Creative Commons Attribution 4.0 International License (http://creativecommons.org/licenses/by/4.0/), which permits unrestricted use, distribution, and 
activation, thereby is involved in the progress of cancers [4]. Besides its down-regulation of T-cell immunity, B7-H4 might have a direct effect on tumorigenesis independent of immunity. High expression of B7-H4 was found in various tumor tissues and related with adverse clinical course and it may serve as a target to activate anti-cancer immunity [5]. The importance of B7-H4 in the setting of lymphoma was not well studied. It was reported by Wang et al. that high level of serum B7-H4 level may be correlated with lymphoma. [6] However, the role of $\mathrm{B} 7-\mathrm{H} 4$ in $\mathrm{EBV}^{+} \mathrm{DLBCL}$ has not been addressed. Our study examined the expression of EBV in 260 DLBCL samples and tried to know the possible roles of B7-H4 in it.

\section{Methods}

\section{Patients and tissue specimens}

Two hundred and sixty patients diagnosed with DLBCL between January 2005 and November 2017 at the Department of Hematology, Shanghai General Hospital, Shanghai Jiao Tong University School of Medicine were analyzed. All tissues were fixed in 10\% buffered formalin and embedded in paraffin. Samples were routinely stained by hematoxylin and eosin (H\&E) for histological examination. The present study was approved by the Ethics Committee of Shanghai Jiao Tong University School of Medicine affiliated Shanghai General Hospital (No.2018KY258). Informed consent was obtained for experimentation with human subjects.

\section{Cell lines and antibodies}

Pfeiffer cell line derived from human diffuse large B cell lymphoma cells were purchased from ATCC, USA. B95-8 lymphoma cells and EBV-infected marmoset white cells are a gift from Prof. Yao (The First Affiliated Hospital of Medical School of Zhejiang University). Mouse monoclonal antibody (3E8) against human B7-H4 is a gift from Institute of Infectious Diseases affiliated Zhejiang University. Goat anti-rabbit IgG antibodies and horseradish peroxidase (HRP)-conjugated goat anti-mouse IgM were purchased from Santa Cruz Biotechnology (Santa Cruz, Calif., USA). Rabbit antibodies against Bcl-2, phospho-Bcl-2, Bax, caspase 3, cleaved caspase 3, caspase 9, cleaved caspase 9, NF- $\mathrm{kB}$ p65, phosphor-NF- $\mathrm{kB}$ p65, extracellular-regulated kinase 1/2(Erk1/2), phospho-Erk1/2, Akt, phosphor-Akt and HRP-conjugated rabbit anti-D-glyceraldehyde-3-phosphate dehydrogenase (GAPDH) monoclonal antibody were purchased from Cell Signaling Technology (Danvers, Mass., USA).

\section{EBV- encoded small RNA ditection by in situ hybridization(ISH-EBER)}

ISH-EBER analysis was performed by in situ hybridization on sections from formalin-fixed and paraffin-embedded
(FFPE) tissue blocks. The assays were conducted using an ISH kit for EBER-1 (Triplex International Biosciences). Sections were stained with $\mathrm{DAB}$ solution and the reaction was stopped according to microscopic evaluation. The brown nuclear staining was identified as positive staining [7].

\section{B7-H4 immunohistochemistry(IHC)}

Monoclonal antibody (3E8) against B7-H4 was prepared as previous reported [8]. IHC staining was performed using 3E8 as primary antibody followed by reagents from the EnVision System (DAKO, CA, USA). Normal mouse IgM was used as a negative control. Semi-quantitative measurements of staining intensity ( $0-3$, least intense to most intense) and the proportion of stained cells $(0-4$, no stained cell stained to $>75 \%$ stained cells) were counted as previously described [8]. Positive expression of B7-H4 was defined as a combined score of equal or over 2. Overexpression of B7-H4 was defined as a combined score of equal or over 6 .

\section{Preparation of EBV-infected Pfeiffer cell}

Pfeiffer cells $\left(1 \times 10^{6}\right.$ cells $\left./ \mathrm{ml}\right)$ and the B95-8 supernatant were incubated for $2 \mathrm{~h}$ at $37^{\circ} \mathrm{C}$ and cultured for 2 weeks with complete medium and $1 \mu \mathrm{g} / \mathrm{ml}$ of cyclosporine A (Sigma-Aldrich Inc.). EBV stock was extracted from an EBV-infected B95-8 marmoset cell line (a gift from Dr. Yao's lab, The First Affiliated Hospital of Medical School of Zhejiang University). Cells were collected after being infected by EBV for 2, 6, 10 and 14 days. Cells were lysed and the expression of B7-H4 was analyzed by Western blot and flow cytometry. To inhibit B7-H4, we cultured the EBV-infected Pfeiffer cells ( 2 weeks, $5 \times 10^{5}$ cells/well, $200 \mu \mathrm{l}$ ) with anti-B7-H4 antibody $(5 \mu \mathrm{g} / \mathrm{ml})$ at $37^{\circ} \mathrm{C}$ for $3 \mathrm{~h}$.

\section{Live cell assay}

The cells were collected and seeded in triplicate in a 96well plate. The proportion of live cells was measured by using a CellTiter 96 AQueous One Solution Cell Proliferation Assay kit (MTS; Promega) after 1 to 5 days. Absorbance at $490 \mathrm{~nm}$ was measured by model 680 microplate reader after cells were incubated for $4 \mathrm{~h}$ at $37^{\circ} \mathrm{C}$.

\section{Apoptosis assay}

The cells were collected after 3 days of incubation with anti-B7-H4 antibody, resuspended in $100 \mu \mathrm{l}$ of annexin V-binding buffer (10 mM HEPES/NaOH pH 7.4, 140 $\mathrm{mM} \mathrm{NaCl}, 2.5 \mathrm{mM} \mathrm{CaCl}{ }_{2}$ ) followed by stainning with FITC-conjugated annexin V (BD Pharmingen) and propidium iodide (BD Pharmingen) in dark at room temperature for $15 \mathrm{~min}$. Stained cells were analyzed using a FACS Calibur (BD Pharmingen) [9]. 


\section{Western blots}

The cells $\left(1 \times 10^{7}\right.$ cells/sample) were washed in cold PBS and lysed in cell lysis buffer (20 mM Tris- $\mathrm{HCl}$ (pH 7.5), $150 \mathrm{mM} \mathrm{NaCl}, 1 \mathrm{mM} \mathrm{Na}{ }_{2}$ EDTA, $1 \mathrm{mM}$ EGTA, $1 \%$ Triton, $2.5 \mathrm{mM}$ sodium pyrophosphate, $1 \mathrm{mM}$ beta-glycerophosphate, $1 \mathrm{mM} \mathrm{Na} \mathrm{VO}_{4}$, and $1 \mu \mathrm{g} / \mathrm{ml}$ leupeptin) (Cell Signaling Technology), and incubated on ice for 30 min. The insoluble material was removed by centrifugation at $8,000 \mathrm{~g}$ for $10 \mathrm{~min}$. The concentration of protein was determined using BCA protein assay kit (Pierce). Lysates were separated by $12 \%$ SDS-PAGE and transferred to nitrocellulose membranes. After blocking with $5 \%$ skim milk, the blots were probed for $2 \mathrm{~h}$ with primary antibodies and further incubated with secondary antibodies (peroxidase-conjugated goat anti-rabbit IgG at 1:5000 or peroxidase-conjugated sheep anti-mouse IgG at 1:2000) for $1 \mathrm{~h}$ at room temperature. The blots were developed using an ECL kit (Amersham Pharmacia).

\section{Statistical analysis}

Statistical analysis was performed with SPSS 23.0 software. Differences among categorical variables were evaluated by the Chi Square test. Survival distributions were estimated with the Kaplan- Meier method and groups were compared with the log-rank test. Data is judged to be statistically significant when $p<0.05$.

\section{Results}

$E B V^{+} D L B C L$ patients show a more aggressive clinical course To observe the prognosis of the $\mathrm{EBV}^{+}$DLBCL patients, we retrospectively analyzed the two hundred and sixty patients with a median age of 55 years (15 to 85 years) diagnosed with DLBCL by dividing patients into two cohorts based on the presence of EBV $\left(E B V^{+} D L B C L\right.$ and EBV ${ }^{-}$DLBCL). We recorded the clinical features of all DLBCL patients as shown in Table 1. We performed the in-situ hybridization Epstein-Barr virus (EBV)-encoded RNA (ISH-EBER) assay on sections from these patients and found $\mathrm{EBV}^{+}$tumour cells in 16 cases (6.2\%) with the age ranged between 38 and 84 years (median age: 58.5 years)(Fig. 1a-d). We recorded the clinical features of all DLBCL patients as shown in Table 1. Interestingly, the overall survival (OS) rate and progression-free survival (PFS) rate were significantly lower in $\mathrm{EBV}^{+} \mathrm{DLBCL}$ patients than in $\mathrm{EBV}^{-}$DLBCL patients (2 year OS rate: $51.9 \%$ vs $84.9 \%, P=0.0001$; 2 year $\mathrm{PFS}$ rate: $51.9 \%$ vs $80.3 \%, P=0.0015)$ (Fig. 1f-g).

Table 1 Clinical characteristics of patients with DLBCL

\begin{tabular}{|c|c|c|c|c|c|c|c|}
\hline \multirow[t]{2}{*}{ Characteristics } & \multicolumn{2}{|l|}{ Total $(n=260)$} & \multicolumn{2}{|c|}{ EBV-positive $(n=16)$} & \multicolumn{2}{|c|}{ EBV-negative $(n=244)$} & \multirow{2}{*}{$\begin{array}{l}P \\
\text { value }\end{array}$} \\
\hline & No. & $\%$ & No. & $\%$ & No. & $\%$ & \\
\hline Sex(male/female) & \multicolumn{2}{|l|}{$260(157 / 103)$} & \multicolumn{2}{|l|}{$16(11 / 5)$} & \multicolumn{2}{|l|}{ 244(146/98) } & 0.492 \\
\hline Age(y) median(range) & \multicolumn{2}{|l|}{$55(15-85)$} & \multicolumn{2}{|l|}{$58.5(38-84)$} & \multicolumn{2}{|l|}{$55(15-85)$} & \\
\hline \multicolumn{8}{|l|}{ Subgroup } \\
\hline GCB & $66 / 176$ & 37.5 & $5 / 15$ & 33.3 & $61 / 161$ & 37.9 & 0.727 \\
\hline non-GCB & $110 / 176$ & 63.5 & $10 / 15$ & 66.7 & $100 / 161$ & 62.1 & \\
\hline \multicolumn{8}{|l|}{ Initial Chemotherapy } \\
\hline $\mathrm{R}-\mathrm{CHOP}$ & $162 / 260$ & 62.3 & $8 / 16$ & 50.0 & $154 / 244$ & 63.1 & 0.294 \\
\hline $\mathrm{CHOP}$ & $69 / 260$ & 26.5 & $4 / 16$ & 25.0 & $65 / 244$ & 26.6 & 0.886 \\
\hline other & $18 / 260$ & 6.9 & $1 / 16$ & 6.3 & $17 / 244$ & 7.0 & 0.913 \\
\hline no treatment & $11 / 260$ & 4.2 & $3 / 16$ & 18.8 & $8 / 244$ & 3.3 & 0.003 \\
\hline \multicolumn{8}{|l|}{ Therapeutic response } \\
\hline$C R$ & $108 / 228$ & 47.6 & $2 / 12$ & 16.7 & $106 / 216$ & 49.1 & 0.029 \\
\hline$P R$ & $45 / 228$ & 19.8 & $4 / 12$ & 33.3 & $41 / 216$ & 19.0 & 0.224 \\
\hline SD & $4 / 228$ & 1.8 & $0 / 12$ & 0.0 & $4 / 216$ & 1.9 & 0.634 \\
\hline PD & $71 / 228$ & 31.3 & $6 / 12$ & 50.0 & $65 / 216$ & 30.1 & 0.147 \\
\hline \multicolumn{8}{|l|}{ Clinical stage } \\
\hline I & $32 / 251$ & 12.7 & $1 / 15$ & 6.7 & $31 / 236$ & 13.1 & 0.466 \\
\hline ॥ & $39 / 251$ & 15.5 & $1 / 15$ & 6.7 & $38 / 236$ & 16.1 & 0.328 \\
\hline III & $58 / 251$ & 23.1 & $0 / 15$ & 0 & $58 / 236$ & 24.6 & 0.029 \\
\hline IV & $122 / 251$ & 48.6 & $13 / 15$ & 86.7 & $109 / 236$ & 46.2 & 0.002 \\
\hline B symptoms present & $95 / 260$ & 36.5 & $10 / 16$ & 62.5 & $85 / 244$ & 34.8 & 0.026 \\
\hline
\end{tabular}

$C R$ Complete remission, $P R$ Partial remisssion, $S D$ Stable disease, $P D$ Progression of disease, $R$ Rituximab 
A

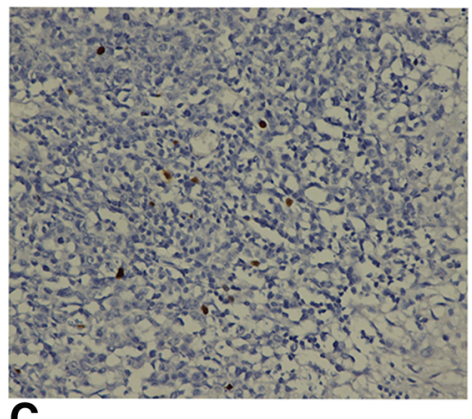

C
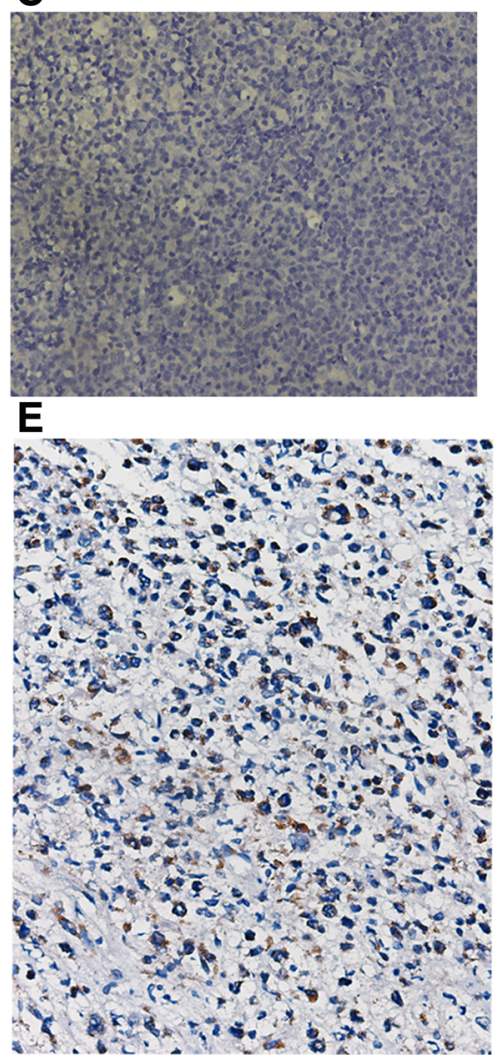

B

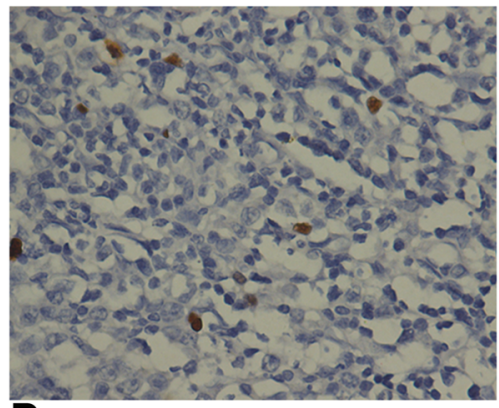

D

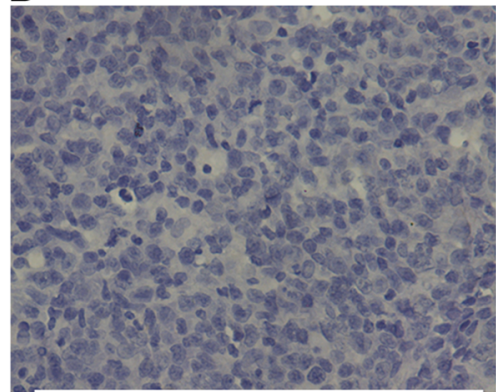

Overall survival

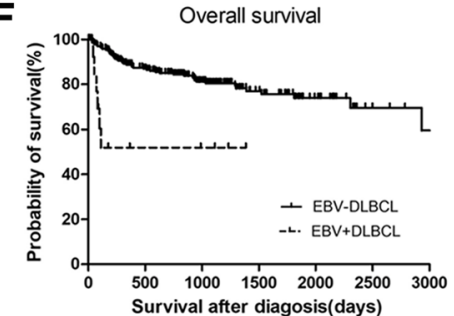

G

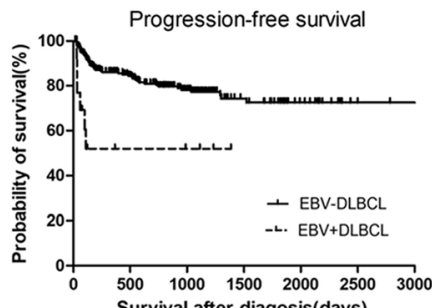

Fig. 1 Histopathological features and survival analysis of patients with DLBCL. a-b ISH-EBER shows positivity with brown staining, (a) $20 \times 40$ and (b) $40 \times 40$. c-d. ISH-EBER shows negativity, (c) $20 \times 40$ and (d) $40 \times 40$. e Different sample from EBV ${ }^{+}$DLBCL patients was subjected to IHC staining using B7-H4 antibody 3E8. Normal mouse lgG was used as the negative control (Data not shown). Representative DLBCL sample with positive B7H4 expression was used by Semi-quantitative measurement. Total score of this sample is 5 (intensity 3 plus proportion 2). $\mathbf{f}-\mathbf{g}$ Overall survival (OS) (f) and progression-free survival (PFS) $(\mathbf{g}) \mathrm{EBV}^{+} \mathrm{DLBCL}(n=16)$ and EBV DLBCL $(n=244)$. EBV ${ }^{+} \mathrm{DLBCL}$ patients had poorer prognoses than EBVDLBCL patients (2 year OS rate: $51.9 \%$ vs $84.9 \%, P=0.0001 ; 2$ year PFS rate: $51.9 \%$ vs $80.3 \%, P=0.0015$ )

\section{Significantly enhanced expression of $\mathrm{B} 7-\mathrm{H} 4$ in $\mathrm{EBV}^{+} \mathrm{DLBCL}$ patients}

To determine the expression of $\mathrm{B} 7-\mathrm{H}_{4}$ in $\mathrm{EBV}^{+}$and $\mathrm{EBV}-$ cohorts, we used IHC staining of B7-H4 in 16 tissue sections from $\mathrm{EBV}^{+} \mathrm{DLBCL}$ patients and 155 tissue sections from EBV DLBCL patients. We observed that 13 (81.3\%) out of 16 tissue sections from $\mathrm{EBV}^{+}$DLBCL patients and 121 (78\%) out of 155 tissue sections from EBV DLBCL patients stained positive for B7-H4 $(P=0.768)$ (Fig. 1e).
However, B7-H4 was markedly more overexpressed in $\mathrm{EBV}^{+} \mathrm{DLBCL}(54 \%, 7 / 13)$ than that in EBV DLBCL (7\%, $11 / 155)$ as scored by staining intensity and proportion of positively stained cells $(P=0.000)$ (Table 2 ).

Inhibition of B7-H4 led to decreased cell viability and enhanced apoptosis in EBV-infected Pfeiffer cells We further investigated whether EBV infection causes B7-H4 overexpression in Pfeiffer cells which expresses 
Table 2 The expression of $\mathrm{B} 7-\mathrm{H} 4$ in $\mathrm{EBV}^{+}$and $\mathrm{EBV}$ DLBCL patients

\begin{tabular}{llll}
\hline Group & EBV $^{+} \mathrm{DLBCL}$ & $\mathrm{EBV}^{-} \mathrm{DLBCL}$ & $P$ value \\
\hline No. of B7-H4 expression & & & \\
Negative & $3(18.75 \%)$ & $34(21.94 \%)$ & 0.768 \\
Positive & $13(81.25 \%)$ & $121(78.06 \%)$ & \\
Overexpression & $7(43.75 \%)$ & $11(7.09 \%)$ & 0.000 \\
Case no. & 16 & 155 & \\
\hline
\end{tabular}

B7-H4. We found that B7-H4 was lowly expressed on surface of Pfeiffer cells without EBV infection, but gradually increased at day 2, 6 and 10 after infection of EBV (Fig. 2). This result is consistent with our observation in $\mathrm{EBV}^{+} \mathrm{DLBCL}$ patients. Moreover, we detected substantially increased live cells and declined apoptosis in EBVinfected Pfeiffer cells (Fig. 3a-b). Importantly, when treated with anti-B7-H4 antibody which inhibits the expression of B7-H4, EBV-infected Pfeiffer cells dropped and the apoptosis was increased (Fig. 3b-c).

\section{Inhibition of B7-H4 led to apoptosis of EBV-infected Pfeiffer cells via caspase activation}

To explore the mechanism through which B7-H4 inhibited apoptosis, we analyzed caspase 3 and caspase 9 by Western blot in EBV-infected Pfeiffer cells. We noticed that inhibition of $\mathrm{B} 7-\mathrm{H} 4$ increased the expression of cleaved caspase 3 and cleaved caspase 9. When cells were treated with caspase 3 inhibitor (Z-DEVD-fmk) and caspase 9 inhibitor (Z-LEHD-fmk) before incubation with anti-B7-H4 antibodies, expression of cleaved caspase 3 and cleaved caspase 9 significantly decreased compared with in EBV-infected Pfeiffer cells treated with anti-B7-H4 antibody only (Fig. 4). We next analyzed whether Bax and Bcl-2 plays a role in B7-H4 mediated inhibition of apoptosis. As shown in Fig. 4, the proapoptotic protein Bax was increased by anti-B7-H4 treatment, while the anti-apoptotic protein $\mathrm{Bcl}-2$ was decreased after B7-H4 inhibition. These data suggest that in addition to caspase 3 and 9, B7-H4 suppressed apoptosis through altering the $\mathrm{Bcl}-2 / \mathrm{Bax}$ ratio. Furthermore, we found that B7-H4 directly regulated the activation of Erk1/2 and Akt by Western blot analysis. As shown in Fig. 4, inhibition of B7-H4 reduced the phosphorylation of Erk1/2 and Akt.

\section{Discussion}

Several studies reported that $\mathrm{EBV}^{+} \mathrm{DLBCL}$ patients had worse prognosis when compared to EBV DLBCL patients (5 year OS rates of $25 \%$ in $\mathrm{EBV}^{+} \mathrm{DLBCL}$ and $65 \%$ in $E B V$ DLBCL) $[1,10]$. Morales et al. found that 11 cases (15\%) positive for ISH-EBER were associated with poor prognosis. The median $\mathrm{OS}$ in $\mathrm{EBV}^{+} \mathrm{DLBCL}$ was 7 months compared with 47 months in EBV DLBCL [11]. Similar findings were reported in other studies $[12,13]$.

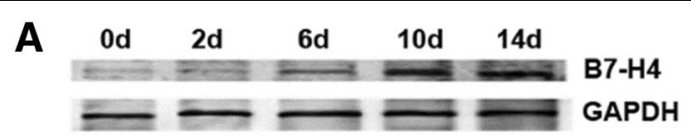

B

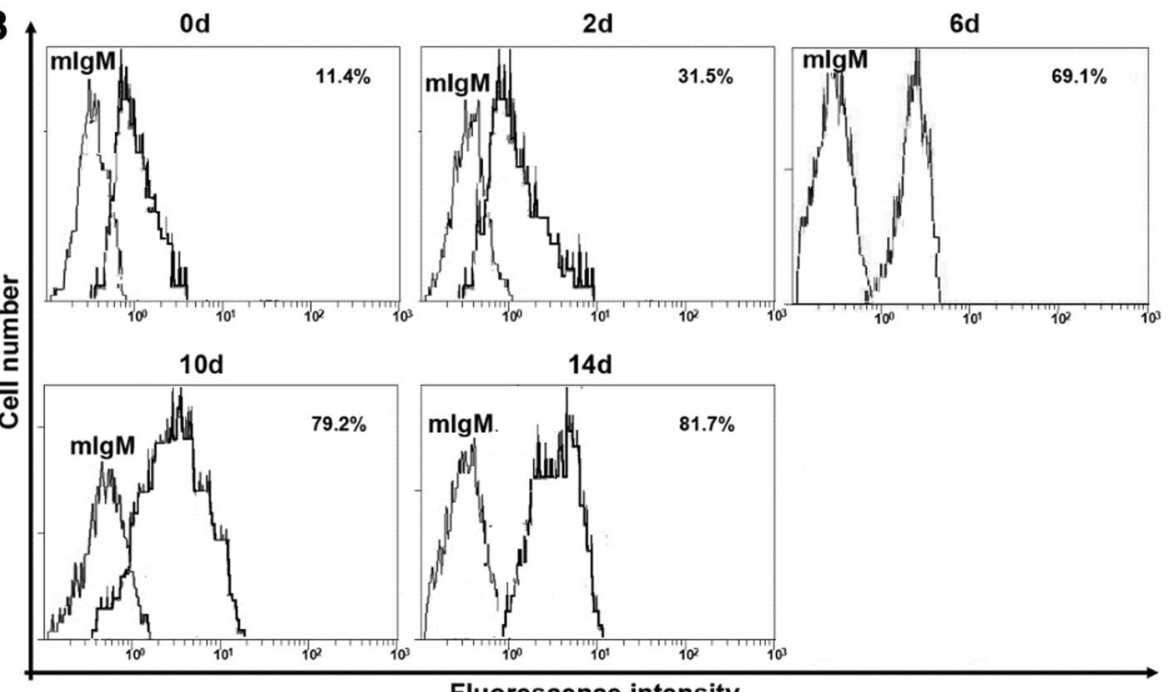

Fig. 2 B7-H4 expression on EBV-infected Pfeiffer cells. Pfeiffer cells were infected with EBV for 0,2,6,10,14 days. Cells were collected from each time point for analysis. a Cellular proteins were analyzed by Western blotting analysis with 3 E8 anti-B7-H4 monoclonal antibodies. b Flow cytometry analysis with 3 E8 mAb. Normal mouse IgM was used as a negative control. Cells were resuspended in a solution of FITC-goat anti-mouse IgM. Finally, cells were analyzed using a FACScan flow cytometer 


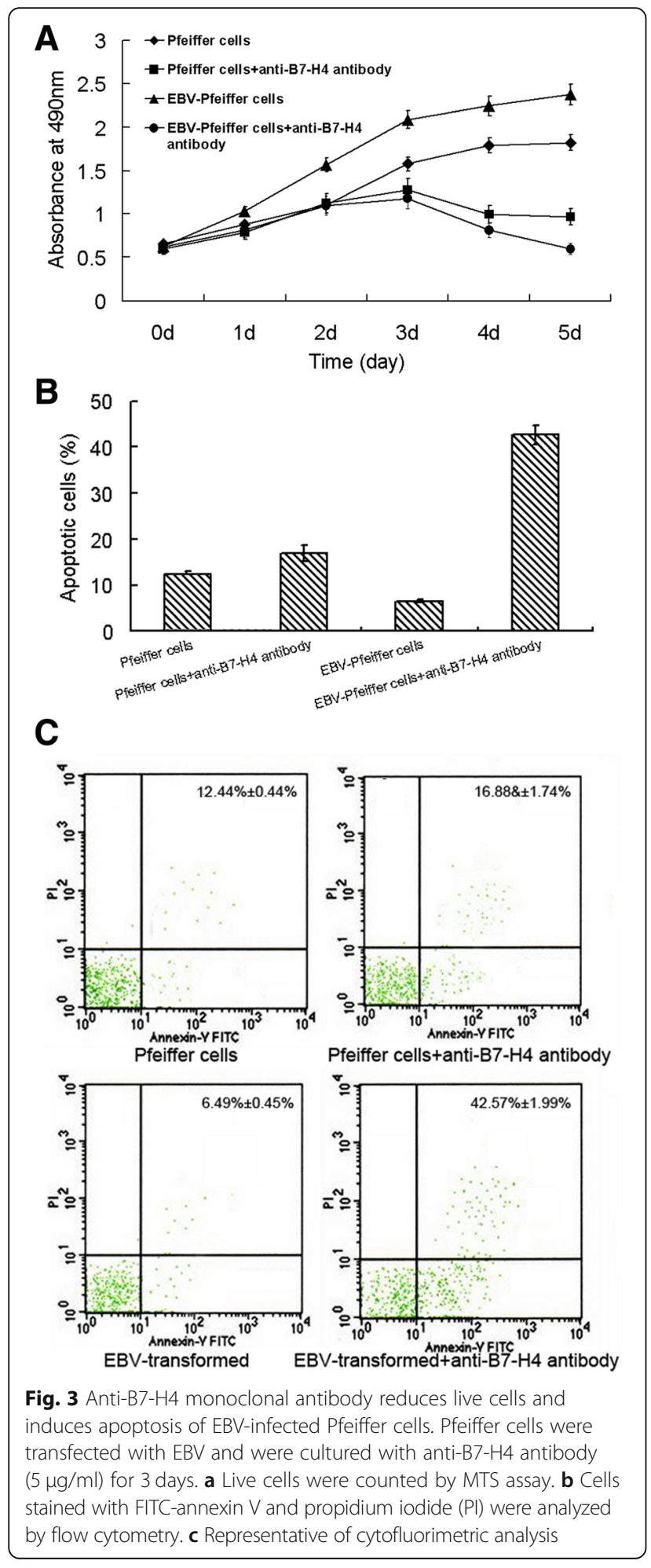

In line with these data, we also found the worse outcome of $\mathrm{EBV}^{+} \mathrm{DLBCL}$ patients compared with $\mathrm{EBV}-\mathrm{DLBCL}$ patients ( 2 year OS rate: $51.9 \%$ vs $84.9 \%, P=0.0001$; 2 year PFS rate: $51.9 \%$ vs $80.3 \%, P=0.0015$, Fig. 1f-g).

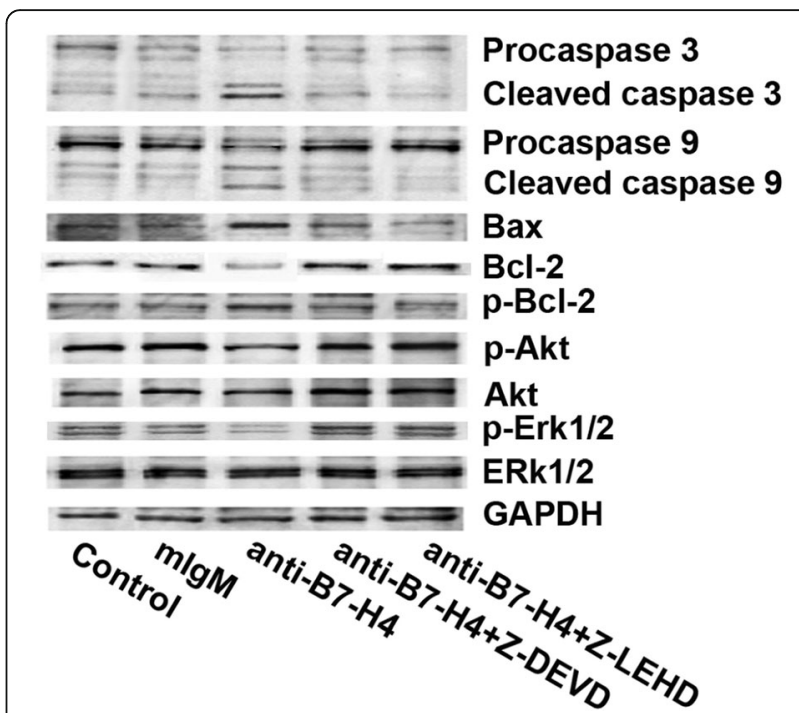

Fig. 4 Anti-B7-H4 antibody upregulates apoptotic proteins and downregulates mitogenic signaling. EBV-infected Pfeiffer cells were cultured with or without the Z-DEVD-fmk (caspase 3 inhibitor) or Z-LEHD-fmk (caspase 9 inhibitor) for $2 \mathrm{~h}$ before stimulation with anti-B7-H4 antibodies $(5 \mu \mathrm{g} / \mathrm{ml})$ for 3 days. Cellular proteins were observed by Western blotting after $72 \mathrm{~h}$ with antibodies of $\mathrm{BCl}-2$, p-Bcl-2, Bax, caspase 3, caspase 9, p-Akt, Akt, p-Erk1/2, Erk1/2 and GAPDH

T-cell mediated anti-tumor immunity plays an important role in preventing tumorigenesis. The classic B7 family provides costimulatory signals to regulate $\mathrm{T}$-cell response. Blocking the negative costimulatory signals such as PD-1 improved immune response in lymphoma [14]. Besides PD-1, B7-H4 has been raised importance as another targetable checkpoint inhibitor. B7-H4 is a member the B7 superfamily, which was highly expressed across a wide variety of malignancies and was correlated with tumor aggressiveness via inhibiting T-cell activation [5, 15-17]. Recently, 13 types of cancers including melanoma, prostate, stomach, lung, ovary, cervix, kidney, colon, breast, liver and pancreas cancer, were reported to correlate with B7-H4 in retrospective analyses [18-23]. Furthermore, B7-H4 might regulate tumorigenesis beside its function immunity. Increased B7-H4 expression in tumor cells was correlated with decreased cell apoptosis and enhanced growth of tumor cells. Thus, B7-H4 may serve as an effective biomarker for cancer diagnosis and prognosis [24]. The role of $\mathrm{B} 7-\mathrm{H} 4$ is unclear in DLBCL, which is the most common type of Non-Hodgkin's lymphoma (NHL). In our study, we found for the first time that the expression of B7-H4 was largely enriched in $\mathrm{EBV}^{+}$DLBCL compared with that in EBV DLBCL, suggesting a critical role of B7$\mathrm{H} 4$ in the development of $\mathrm{EBV}^{+} \mathrm{DLBCL}$. These results indicate the $\mathrm{B} 7-\mathrm{H} 4$ might serve as a critical mediator the development of EBV ${ }^{+}$DLBCL.

Previously, Song et al. reported enhanced expression of B7-H4 induced apoptosis in $\mathrm{EBV}^{+} \mathrm{B}$ cells [9]. 
Interestingly, EBV-infected cells were able to escape immune surveillance via B7-H4 [25]. These data implies that B7-H4 may inhibit the proliferation and induce apoptosis of B cells to weaken the production of immunoglobulin, thus suppresses adaptive immunity. Song et al. further reported that B7-H4 significantly reduced cell growth via downregulating CDK4/6, CDK2, cyclin E and cyclin D, and enhanced apoptosis in lymphoma cell lines [26]. Conversely, Qian et al. showed that B7-H4 activation enhanced oncogenicity and inhibited apoptosis in pancreatic cancer cells [27]. The studies add the complexity of the role of $\mathrm{B} 7-\mathrm{H} 4$ in oncogenesis. We further elucidated the relationship between EBV and B7-H4 by infecting the DLBCL cell line Pfeiffer cells with EBV. We found that the expression of $\mathrm{B} 7-\mathrm{H} 4$ was upregulated in EBV-infected Pfeiffer cells, which increased live cells and reduced apoptosis. These in vitro results indicate that B7-H4 may contribute to transformation of lymphoma by EBV infection in vivo.

To determine the molecular mechanism underlying the function B7-H4 in EBV-infected cells, we utilized the antiB7-H4 monoclonal antibody (3E8) which inhibited B7-H4 [28]. We found that B7-H4 by increased cell viability and inhibited apoptosis, suggesting an enhanced oncogenicity of lymphoma cells. Our results are consistent with previous studies. For example, Cheng et al. showed that overexpression of $\mathrm{B} 7-\mathrm{H} 4$ promoted tumorigenesis of ovarian cancer in immunodeficient mice by increasing proliferation, cell adhesion, migration, and invasion of cancer cells [29]. Knockdown of B7-H4 in a breast cancer cell line increased caspase activity and apoptosis [30]. B7-H4 also enhanced tumor growth and inhibited apoptosis in pancreatic cancer [27]. Here, we showed that B7-H4 contributed to the surviving of DLBCL cells. It's worth mentioning that our results disagree with the study by Park et al. which showed cell cycle arrest and apoptosis in $\mathrm{B} 7-\mathrm{H}_{4}^{+}$ lymphoma cell lines (Raji and IM-9 cells). The discrepancy is likely to be a result of different lymphoma cell lines and anti-B7-H4 antibody used. In our study, we used Pfeiffer cell for study because this cell line is one of DLBCL cell lines without the expression of B7-H1. Otherwise, it may confuse our investigation of $\mathrm{B} 7-\mathrm{H} 4$.

Many anti-cancer drugs aim at inducing apoptosis [31]. The increased Bax/Bcl-2 ratio is likely to be followed by cytochrome $C$ release, caspases $9,3,6$, and 7 activation, which eventually lead to apoptosis [32]. Also Erk1/2 and PI3K/Akt pathway is a critical regulator of apoptosis by directly phosphorylating and inactivating caspase $3,6,8$, and 9 $[33,34]$. Park et al. reported that B7-H4 modulated the cell cycle through downregulating of the Akt in $\mathrm{EBV}^{+} \mathrm{B}$-cell lymphoma [26]. Indeed, our data showed that caspases 9 and 3 were activated and the $\mathrm{Bax} / \mathrm{Bcl}-2$ ratio was altered after inhibition of B7-H4 in EBV-infected Pfeiffer cells caused apoptosis. In our study, inhibition of B7-H4 by anti-
B7-H4 antibody also reduced the protein level of phosphoErk1/2 and phospho-Akt, suggesting that B7-H4 is responsible for inhibition of apoptosis via upregulating the Erk1/2 and Akt signalling pathway. Taken together, these findings demonstrate that $\mathrm{B} 7-\mathrm{H} 4$ effectively inhibit apoptosis via multiple pathways including caspases 3 and $9, \mathrm{Bcl}-2$ and Bax as well as Erk1/2 and Akt signalling pathways.

\section{Conclusion}

Our study demonstrated that B7-H4 was highly expressed in $\mathrm{EBV}^{+} \mathrm{DLBCL}$ which showed a more aggressive clinical course than EBV DLBCL. Consistently, the infection of DLBCL cell line by EBV increased the expression of B7H4. B7-H4 promoted cell viability by inhibiting apoptosis in EBV-infected DLBCL cell line via Erk1/2 and Akt pathway. Thus, we revealed a critical role of B7-H4 may in development of EBV ${ }^{+}$DLBCL. These data shed light on $\mathrm{B} 7-\mathrm{H} 4$ as a potential therapeutic target in $\mathrm{EBV}^{+} \mathrm{DLBCL}$ patients. Future studies are required to test the function of $\mathrm{B} 7-\mathrm{H} 4$ in vivo. Besides, due to the rarity of $\mathrm{EBV}^{+} \mathrm{DLBCL}$ patients, collaborative studies among multiple institutions are warranted.

\begin{abstract}
Abbreviations
DLBCL: Diffuse large B cell lymphoma; EBV: Epstein-Barr Virus; $\mathrm{EBV}^{+} \mathrm{DLBCL}$ : Epstein-Barr Virus-Positive diffuse large B cell lymphoma; EBV DLBCL: Epstein-Barr Virus negative diffuse large B cell lymphoma; Erk1/ 2: Extracellular-regulated kinase 1/2; FFPE: Formalin-fixed and paraffinembedded; H\&E: Hematoxylin and eosin; HRP: Horseradish peroxidase; ISHEBER: EBV-encoded small RNA with in situ hybridization; OS: Overall survival; PFS: Progression-free survival
\end{abstract}

\section{Acknowledgements}

Not applicable.

\section{Authors' contributions}

YJ: collected the clinical information and wrote this manuscript. GC and JL: took part in the laboratory work and contributed to the development of the proposal. JZ, ZB and YL: took part in the laboratory work. CW: contributed to the development of the proposal and reviewed the manuscript. YT: contributed to the conception of the study and reviewed the manuscript. All authors read and approved the final manuscript.

\section{Funding}

This work was supported by the Science Technology Research Plan of Jinhua Province [Grant number 2017-4-045]; National Natural Science Foundation [Grant number 81670139]; and Natural Science Foundation of Shanghai [Grant number 16ZR1427800].

Availability of data and materials

Not applicable.

Ethics approval and consent to participate

The present study was approved by the Ethics Committee of Shanghai Jiao Tong University School of Medicine affiliated Shanghai General Hospital (No.2018KY258).

Consent for publication

Not applicable.

Competing interests

The authors declare that they have no competing interests. 


\section{Author details}

${ }^{1}$ Department of Hematology, Shanghai General Hospital, Shanghai Jiao Tong University School of Medicine, 100 Haining Road, Shanghai 200080, People's Republic of China. ${ }^{2}$ Department of Hematology, JinHua Hospital of TCM, 439 Shuangxi West Road, Jinhua 321017, People's Republic of China. ${ }^{3}$ Department of Pathology, Shanghai General Hospital, Shanghai Jiao Tong University School of Medicine, 100 Haining Road, Shanghai 200080, People's Republic of China. ${ }^{4}$ Department of Integrated Therapy, Fudan University Shanghai Cancer Center, 270 Dongan Road, Shanghai 200032, People's Republic of China.

Received: 14 March 2019 Accepted: 22 July 2019

Published online: 08 August 2019

\section{References}

1. Castillo JJ, Beltran BE, Miranda RN, Young KH, Chavez JC, Sotomayor EM. EBVpositive diffuse large B-cell lymphoma of the elderly: 2016 update on diagnosis, risk-stratification, and management. Am J Hematol. 2016;91(5):529-37.

2. Battle-Lopez A, Gonzalez de Villambrosia S, Nunez J, Cagigal ML, MontesMoreno $\mathrm{S}$, Conde $\mathrm{E}$, et al. Epstein-Barr virus-associated diffuse large B-cell lymphoma: diagnosis, difficulties and therapeutic options. Expert Rev Anticancer Ther. 2016;16(4):411-21.

3. Zhang J, Medeiros LJ, Young $\mathrm{KH}$. Cancer immunotherapy in diffuse large Bcell lymphoma. Front Oncol. 2018;8:351.

4. Prasad DV, Richards S, Mai XM, Dong C. B7S1, a novel B7 family member that negatively regulates T cell activation. Immunity. 2003;18(6):863-73.

5. Podojil JR, Miller SD. Potential targeting of B7-H4 for the treatment of cancer. Immunol Rev. 2017;276(1):40-51.

6. Wang XM, Hu GY, Liu W, Zheng SH, Lv J, Wang HM, et al. Clinical significance of determination of serum B7-H4 in patients with malignant hematologic diseases. Xi Bao Yu Fen Zi Mian Yi Xue Za Zhi. 2010;26(9):893-4.

7. Garady C, Saieg MA, Ko HM, Geddie WR, Boerner SL, da Cunha Santos G. Epstein-Barr virus encoded RNA detected by in situ hybridization using cytological preparations. Cytopathology. 2014;25(2):101-7.

8. Qian Y, Shen L, Xu C, Wu Z, Brockmeyer NH, Altmeyer P, et al. Development of a novel monoclonal antibody to $\mathrm{B} 7-\mathrm{H} 4$ : characterization and biological activity. Eur J Med Res. 2011;16(7):295-302.

9. Song H, Park G, Kim YS, Hur I, Kim H, Ryu JW, et al. B7-H4 reverse signaling induces the apoptosis of EBV-transformed B cells through Fas ligand upregulation. Cancer Lett. 2008;266(2):227-37.

10. Oyama T, Yamamoto K, Asano N, Oshiro A, Suzuki R, Kagami Y, et al. Agerelated EBV-associated B-cell lymphoproliferative disorders constitute a distinct clinicopathologic group: a study of 96 patients. Clin Cancer Res. 2007:13(17):5124-32.

11. Morales D, Beltran B, De Mendoza FH, Riva L, Yabar A, Quinones P, et al. Epstein-Barr virus as a prognostic factor in de novo nodal diffuse large Bcell lymphoma. Leuk Lymphoma. 2010;51(1):66-72.

12. Sato A, Nakamura N, Kojima M, Ohmachi K, Carreras J, Kikuti YY, et al. Clinical outcome of Epstein-Barr virus-positive diffuse large B-cell lymphoma of the elderly in the rituximab era. Cancer Sci. 2014;105(9):1170-5.

13. Montes-Moreno S, Odqvist L, Diaz-Perez JA, Lopez AB, de Villambrosia SG, Mazorra F, et al. EBV-positive diffuse large B-cell lymphoma of the elderly is an aggressive post-germinal center B-cell neoplasm characterized by prominent nuclear factor-kB activation. Mod Pathol. 2012;25(7):968-82

14. Bachy E, Coiffier B. Anti-PD1 antibody: a new approach to treatment of lymphomas. The Lancet Oncol. 2014;15(1):7-8.

15. MacGregor HL, Ohashi PS. Molecular pathways: evaluating the potential for B7-H4 as an Immunoregulatory target. Clin Cancer Res. 2017;23(12):2934-41.

16. Chen X, Tao L, Yuan C, Xiu D. The prognostic value of B7-H4 in pancreatic cancer: systematic review and meta-analysis. Medicine. 2018;97(12):e0088.

17. Zhou D, Zhou Y, Li C, Yang L. Silencing of B7-H4 suppresses the tumorigenicity of the MGC-803 human gastric cancer cell line and promotes cell apoptosis via the mitochondrial signaling pathway. Int J Oncol. 2018;52(4):1267-76.

18. Zang X, Thompson RH, Al-Ahmadie HA, Serio AM, Reuter VE, Eastham JA, et al. B7-H3 and B7x are highly expressed in human prostate cancer and associated with disease spread and poor outcome. Proc Natl Acad Sci U S A. 2007;104(49):19458-63.

19. Quandt D, Fiedler E, Boettcher D, Marsch W, Seliger B. B7-h4 expression in human melanoma: its association with patients' survival and antitumor immune response. Clin Cancer Res. 2011;17(10):3100-11.
20. Arigami T, Uenosono $Y$, Hirata M, Hagihara T, Yanagita S, Ishigami S, et al. Expression of B7-H4 in blood of patients with gastric cancer predicts tumor progression and prognosis. J Surg Oncol. 2010;102(7):748-52.

21. Sun Y, Wang Y, Zhao J, Gu M, Giscombe R, Lefvert AK, et al. B7-H3 and B7-H4 expression in non-small-cell lung cancer. Lung Cancer. 2006;53(2):143-51.

22. Kryczek I, Wei S, Zhu G, Myers L, Mottram P, Cheng P, et al. Relationship between $\mathrm{B} 7-\mathrm{H} 4$, regulatory $\mathrm{T}$ cells, and patient outcome in human ovarian carcinoma. Cancer Res. 2007;67(18):8900-5.

23. Krambeck AE, Thompson RH, Dong H, Lohse CM, Park ES, Kuntz SM, et al. B7-H4 expression in renal cell carcinoma and tumor vasculature: associations with cancer progression and survival. Proc Natl Acad Sci U S A. 2006;103(27):10391-6.

24. He C, Qiao H, Jiang H, Sun X. The inhibitory role of b7-h4 in antitumor immunity: association with cancer progression and survival. Clin Dev Immunol. 2011;2011(2011):695834.

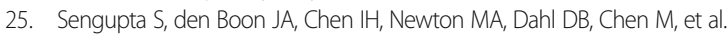
Genome-wide expression profiling reveals EBV-associated inhibition of MHC class I expression in nasopharyngeal carcinoma. Cancer Res. 2006;66(16):7999-8006.

26. Park GB, Song H, Kim YS, Sung M, Ryu JW, Lee HK, et al. Cell cycle arrest induced by engagement of B7-H4 on Epstein-Barr virus-positive B-cell lymphoma cell lines. Immunology. 2009;128(3):360-8.

27. Qian Y, Hong B, Shen L, Wu Z, Yao H, Zhang L. B7-H4 enhances oncogenicity and inhibits apoptosis in pancreatic cancer cells. Cell Tissue Res. 2013;353(1):139-51.

28. Qian Y, Shen L, Cheng L, Wu Z, Yao H. B7-H4 expression in various tumors determined using a novel developed monoclonal antibody. Clin Exp Med. 2011;11(3):163-70

29. Cheng L, Jiang J, Gao R, Wei S, Nan F, Li S, et al. B7-H4 expression promotes tumorigenesis in ovarian cancer. Int J Gynecol Cancer. 2009;19(9):1481-6.

30. Salceda S, Tang T, Kmet M, Munteanu A, Ghosh M, Macina R, et al. The immunomodulatory protein B7-H4 is overexpressed in breast and ovarian cancers and promotes epithelial cell transformation. Exp Cell Res. 2005; 306(1):128-41.

31. Hickman JA. Apoptosis induced by anticancer drugs. Cancer Metastasis Rev. 1992;11(2):121-39.

32. Willis $\mathrm{S}$, Day $\mathrm{CL}$, Hinds MG, Huang DC. The BCl-2-regulated apoptotic pathway. J Cell Sci. 2003;116(Pt 20):4053-6.

33. Georgakis GV, Li Y, Rassidakis GZ, Medeiros LJ, Mills GB, Younes A. Inhibition of the phosphatidylinositol-3 kinase/Akt promotes G1 cell cycle arrest and apoptosis in Hodgkin lymphoma. Br J Haematol. 2006;132(4):503-11.

34. Cardone MH, Roy N, Stennicke HR, Salvesen GS, Franke TF, Stanbridge E, et al. Regulation of cell death protease caspase-9 by phosphorylation. Science. 1998;282(5392):1318-21.

\section{Publisher's Note}

Springer Nature remains neutral with regard to jurisdictional claims in published maps and institutional affiliations.

Ready to submit your research? Choose BMC and benefit from:

- fast, convenient online submission

- thorough peer review by experienced researchers in your field

- rapid publication on acceptance

- support for research data, including large and complex data types

- gold Open Access which fosters wider collaboration and increased citations

- maximum visibility for your research: over $100 \mathrm{M}$ website views per year

At BMC, research is always in progress.

Learn more biomedcentral.com/submissions 